\title{
NOTES TOWARDS A DEFINITION OF ROMANTIC NATIONALISM
}

While the concept 'Romantic nationalism' is becoming widespread, its current usage tends to compound the vagueness inherent in its two constituent terms, Romanticism and nationalism. In order to come to a more focused understanding of the concept, this article surveys a wide sample of Romantically inflected nationalist activities and practices, and nationalistically inflected cultural productions and reflections of Romantic vintage, drawn from various media (literature, music, the arts, critical and historical writing) and from different countries. On that basis, it is argued that something which can legitimately be called 'Romantic nationalism' indeed took shape Europe-wide between 1800 and 1850. A dense and intricately connected node of concerns and exchanges, it affected different countries, cultural fields, and media, and as such it takes up a distinct position alongside political and post-Enlightenment nationalism on the one hand, and the less politically-charged manifestations of Romanticism on the other. A possible definition is suggested by way of the conclusion: Romantic nationalism is the celebration of the nation (defined by its language, history, and cultural character) as an inspiring ideal for artistic expression; and the instrumentalization of that expression in ways of raising the political consciousness.

K E Y W O R D S European Romanticism, Nationalism, Volksgeist, Friedrich Carl von Savigny, Organicism.

\section{Introduction}

The conceptual splicing of Romanticism and nationalism, either as 'Romantic nationalism' or as 'national Romanticism', is becoming increasingly widespread. ${ }^{1}$ 'Romantic nationalism' now has a sizeable Wikipedia entry, and established usage of these terms is found in the fields of nineteenth-century history-writing, music, the arts, and architecture. To some extent this is wholly unsurprising: the two movements arose jointly in the decades around 1800 , shared the turbulent political and social circumstances of that period, and have many important actors in common. Composers like Liszt and Rimsky-Korsakov, poets like Petőfi and Wergeland, novelists like Hendrik Conscience and Felix Dahn, historians like 
Michelet and Palacký, folklorists like Grimm, Asbjørnsen and Moe, are important names in the history both of the Romantic and of the national movements of Europe. Since scholars like Isaiah Berlin and Hans Kohn began to address the intellectual history of nationalism, the interaction and overlap with Romanticism has been habitually noted, especially, of course, in the case of Germany, ${ }^{2}$ where the interactions between the intellectuals of the Romantic generation and the anti-Napoleonic Befreiungskriege were too obvious to be ignored - too obvious even to be scrutinized as anything other than wholly and unproblematically selfevident. The connection between Romanticism and nationalism was usually seen as a situational one: the two arose simultaneously, concurrently, in one specific part of the world at one particular historical moment, and therefore unavoidably shared common features, interactions, and cross-currents.

The activities of intellectuals in both spheres was noted, but without much attention to the question of how precisely the poetics of Romanticism could chime, intellectually, with the ideological doctrine of nationalism. In the 1980 os and 1990s, the 'Romantic-nationalist-nexus' became an analytical lens or conceptual framework for research, mainly on Central European intellectuals of the early-to-mid-nineteenth century. Since then, the concept has begun to move beyond the status of a mere container term, indicating a loosely-observed synchronicity, ${ }^{3}$ towards that of a specific nodal point in the history of ideas. ${ }^{4}$

By now, we may have reached the stage where the 'Romantic-nationalist-nexus' deserves typological specification, for it is not entirely as unproblematic as its widespread usage might lead us to believe. In the various individual cultural sciences, the term is applied to fields as diverse as literature, architecture, painting, music, or folklore, ${ }^{5}$ without much meta-theoretical reflection, let alone with due attention to its usage in adjacent fields. This imposes the need for interdisciplinary cross-calibration. Furthermore, the field of nationalism studies has tended to move away from the intellectual history approach of mid-century scholars like Berlin and Kohn; the emphasis now being, on the whole, more politological and sociological - fields of study for which the finesse of Romantic poetics, and the intermedial and transnational complexities of the European spread of that movement, is of subordinate importance.

What is more, in this scheme of things the causal relationship between culture and the sociopolitical or institutional infrastructure is regrettably one-directional: culture (and, by implication, Romanticism) is usually seen as a by-product or context, never as an agency, as the sort of thing which stands in need of explanation by relating it to its sociopolitical or institutional parameters. Even studies of nineteenth-century nation-formation which, in the wake of Benedict Anderson, profess an awareness of cultural processes, are prone to such socio-economic reductionism. They tend to reduce 'literature' and 'theatre' to the sociology of 'print capitalism' and 'public playhouses'; to address the public involvement or impact of writers rather than the actual substance of their writings; and when they cite writers, composers or artists, it is as 'celebrity witnesses' of historical events rather than as active participants in their shaping. In elaborating a cor- 
rective to that infrastructural reductionism, and in seeing culture as something more than a mere social ambience or ingrained collective habitus, one must take care not to slip into the opposite, but equally anachronistic error: to reify culture into an anthropological category (as a putative, underlying ethnic identity). Instead, culture, in its agency, should be understood as a historically situated and historically variable praxis of communicated ideas. ${ }^{6}$

Nationalism and Romanticism are both notoriously complex, protean terms, each carrying a huge semantic bandwidth. The splicing of two terms so contested and fuzzy might confuse, rather than focus on precisely what it is that we are discussing. At worst, the notion might mean little more than that the 1848 revolutionaries tended to get carried away by pathos and enthusiasm (yes, they were very Romantic, those nationalists), or that Romantic artists abandoned elite classicism or cosmopolitanism in favour of the vernacular (yes, they were nationalists, those Romantics). Since both nationalism and Romanticism were all-pervasive attitudes in these decades, the notion that many people might be affected by a mixture of both might become a toothless truism. Hence what is needed is a conceptual improvement, identifying which elements in nationalism were particularly congenial to the poetics of Romanticism, and which elements in Romanticism were particularly congenial to nationalism.

In what follows, I want to align some features of Romanticism, as a paradigm in poetics, and nationalism, as a paradigm in political thought, and, with reference to some of the artists/intellectuals involved, outline some elements that render the notion of 'Romantic nationalism' both concrete and discrete. Discrete, in that it specifies the Romantic-nationalism-nexus in terms of a specific intellectual profile that is recognizably and uniquely its own; concrete, in that we can see this profile, not as a theoretical verbal construct of 'the sort of attitudes which we know formed part of that type of -ism', but on the basis of facts: real actions and utterances, undertaken and made by real people at specific moments and in specific places.

To be sure, the historical time-frame (the Sattelzeit with its continuities and discontinuities) is highly meaningful. There are social, political, and institutional events, some of them of a drastically revolutionary nature, which affected both Romanticism and nationalism. Both movements owe as much to Napoleon and to technological innovation as they do to Herder and Rousseau. Without the wars and constitutional upheavals of the period 1792-1815; without the invention of cheap wood-pulp paper and of new high-speed, mass-volume printing techniques; without the institution of state-controlled libraries, archives, museums, education, and university systems, neither Romanticism nor nationalism could have arisen as they did. That does not mean, of course, that the time-frame starts with an instantaneously incisive 'Big Bang'. Romanticism has its pre-1789 run-up (think Ossian, Werther) in what has been called pre-Romanticism, sentimentalism, and/or the Counter-Enlightenment.

So, too, nationalism has its run-up in Enlightenment patriotism, ${ }^{7}$ the civicdemocratic, anti-aristocratic set of political virtues that motivated Pascale Paoli 
in Corsica, the Marseillaise in France, and George Washington and Simon Bolívar in the Americas. Much as the aesthetics of the Sublime, themselves of eighteenthcentury vintage, are still at the heart of Romanticism, so too the ethics of patriotism, itself a Ciceronian-Enlightenment political virtue, are still at the heart of nationalism. Both movements emerge from revolutionary disruptions and discontinuities and try to change and innovate the world; yet both carry within their bosom the older ancestry of Herder and Rousseau. This moral inheritance includes sentimental primitivism, anti-elitism, and anti-classicism, as well as the enduring Enlightenment ideals of anti-absolutism and social improvement by means of reasonable and responsible civic-mindedness.

That enumeration may create the impression that the incisive discontinuities were all political and institutional, while the continuities were all cultural and intellectual. This is not wholly true. In the realm of cultural reflection, some transformations take place which set off the early nineteenth century from the preceding period, and these cultural/intellectual ruptures provide a good point of access to discuss the family resemblance between Romanticism and nationalism. More or less in this order, but with some interweaving, I shall address: [1] the linguistic revolution, [2] the spread of idealism, and [3] the rise of historicist dialectics. In each case, I shall try and indicate both the intermedial and transnational spread of these Romantic principles (across various nationalities and media), and their impact in the field of political thought and emerging nationalism.

\section{The Linguistic Revolution and the Vernacular Turn}

To begin with, there is the elaboration of the Indo-European model of language relations. The story is a familiar one, moving from Sir William Jones's discovery of Sanskrit to Friedrich Schlegel's consolidation and Europe-wide broadcasting of that model in his Über die Sprache und Weisheit der Inder. ${ }^{8}$ In literature, this reinforces an already emerging taste for Oriental tales and provides Romantic authors and painters with a powerful imaginative alternative to the over-used classicist reservoir of cultural imagery.

In intellectual life the implications of this 'vernacular turn' rippled far and wide. ${ }^{9}$ The Indo-European linguistic family tree, a triumph of scientific systematization, lent interest to languages and dialects which until then had been dismissed as uncouth vernaculars spoken by uneducated rustics; and that in turn had an emancipatory effect on the many speakers of those idioms, often in the peripheries of the great empires, which were now gaining serious scholarly attention. Ultimately, this process was to furnish a new criterion of nationality.

Nations were now defined as groups of people identified by a common, separate language. To have one's idiom classified as 'a language' meant that the speakers formed 'a nation'; and that realization either transformed or formed many national movements in the nineteenth century. Groups which until 1800 had primarily identified themselves by means of their legal constitution (current or 
remembered), religion, or historical inheritance, now re-defined their identity, indeed their 'nationality' by the criterion of language (examples range from the Basque country to Hungary and Croatia). Others freshly articulated a newly emerging national identity by using the novel criterion (Estonians, Latvians, Albanians, and Bulgarians). The case of Ireland is especially telling. ${ }^{10}$ After 1830, a pre-existing antiquarian, scholarly interest in Irish-Gaelic began to change into an altogether different discourse: that of the language as a marker of nationality, and indeed the core argument why Ireland could never be fully integrated under English ('Anglo-Saxon') rule. The tipping point is exemplified in the generational shift from Daniel O'Connell to Thomas Davis's Young Ireland movement around 1840. O'Connell (who had a native knowledge of the language) attached little or no symbolical importance to it, and he saw no need to ensure its survival or cultivation into the future. His nationalism was wholly based on the reasoning of constitutional and religious rights and wholly carried through social agitation and parliamentary activism. Davis and the Young Irelanders (gathered around the periodical tellingly called The Nation) based their calls wholly on arguments of cultural descent and specificity, celebrating Irishness and propagating their ideology by means of rousing verse and nativist songs such as 'A Nation Once Again'.

The floating and informal three-tier distinction between dialect variant, language and language family also had a three-tiered impact on cultural stances taken, where, below the level of the national movements proper, there were the manifestations of regionalism among dialect speakers (Walloon, Plattdeutsch) while at the higher level of aggregation there were the pan-movements encompassing entire language families, such as Pan-Slavism. ${ }^{11}$ The demarcations between these levels were, to be sure, floating, impressionistic, and contested; but Slavicism was a poetical reality for the Slovak poet Jan Kollár, erstwhile student at Jena. His sonnet cycle Slava's Danghter (1824) fused his yearning for an unattainable beloved into his equally wistful and idealistic aspiration for the solidarity and emancipation of all Slavs everywhere, from Poland to the Balkans. The cycle became a huge consciousness-raiser among like-minded Slavic readers all over Europe. Kollár followed his poetic Romanticism with an agenda of cultural activism (for instance, his tract on the mutual interrelations between the Slavic nations) and was one of the figureheads of the 1848 Slavic Congress in Prague, masterminded by the Czech historian František Palacký.

Examples could easily be multiplied, from Estonia's Lydia Koidula to Spanish-Galician Rosalía de Castro: poets deploying a subaltern vernacular in order to demonstrate and celebrate its literary capabilities, reach out in cultural solidarity to a native reading constituency, and assert the fully 'national' status of their cultural community. This gesture feeds both into the politics of nationalism and the poetics of Romanticism. Politically, it meshes with the ethno-linguistic origins of many national movements in Europe: almost no cultural or national emancipation movement of the nineteenth century fails to use the argument of linguistic identity as the main trump card among their claims for a place on the European 
map. ${ }^{12}$ Poetically, the gesture meshes with the Romantics' new penchant for the literary registers of lyricism and balladry as expressions of authentic simplicity. From the German discovery of the Lied to Wordsworth's celebration of artless spontaneity and emotional authenticity in the Preface to the Lyrical Ballads, the valorisation of 'language really used by men', the rejection of the established high style with its artificial conventions, constitutes one of those revolutionary shifts which sets the poetics of Romanticism apart from the preceding literary generations.

\section{The Poetics of Inspiration, the Politics of Idealism}

'Humanity is surrounded by infinity, by the mystery of divinity and of the world' - that is how Uhland begins his 1807 essay 'On the Romantic'. ${ }^{13}$ This tensionfilled juxtaposition of the down-to-earth and the transcendent is one of the most salient and all-pervasive characteristics of the Romantic generation of lyrical poets. Novalis had metaphorically phrased the Romantic oscillation between the banal and the sublime as a mathematical operation, analogous to raising a figure's exponent to a higher power by squaring it (in German: potenzieren, so that 4 becomes 16) or logarithmically bringing it down to its root integer (in German: logarithmisieren, so that 25 becomes 5).

Romantisieren ist nichts als eine qualitative Potenzierung. Das niedre Selbst wird mit einem bessern Selbst in dieser Operation identifiziert. So wie wir selbst eine solche qualit[ative] Potenzenreihe sind. Diese Operation ist noch ganz unbekannt. Indem ich dem Gemeinen einen hohen Sinn, dem Gewöbnlichen ein geheimnisvolles Ansehn, dem Bekannten die Würde des Unbekannten, dem Endlichen einen unendlichen Schein gebe, so romantisiere ich es - Umgekehrt ist die Operation für das Hohere, Unbekannte, Mystische, Unendliche - dies wird durch diese Verknüpfung logarithmisiert - Es bekommt einen geläufigen Ausdruck. ${ }^{14}$

The poetics of 'inspiration', both in Wordsworth's Preface to the Lyrical Ballads and among the contemporary German Romantics, resides uniquely in negotiating the tension between straightforward, simple forms and complex metaphysical meaning. The appeal of simple song lies not simply (as it would have for the Rousseauesque Sentimentalists of the previous generation) in its touching artlessness, but in its capacity of intuiting the transcendent through its humdrum manifestations and expressing it in a small formal compass. Wordsworth's childlike natural piety triggers intimations of immortality, his youthful nut-beating gives way to a sense of spirits in the wood, his solitary highland lass sings songs that not only make the valley overflow with their sound, but unwittingly echo across the world and the centuries - much as Keats's immortal nightingale was heard in ancient days by emperor and clown, or Shelley's skylark ('bird thou never wert') is not just a feathered animal but something trans-historical.

The 'unpremeditated ecstasy' of Shelley's skylark (so close to Wordsworth's 'spontaneous overflow of powerful feeling') is the type of cantatory response to 
creation which the Romantic poets themselves emulate. The energies feeding literary production lie outside the realm of cerebral cogitation, intellectual control or mastery of form. The poet has, rather, the passively responsive capacity to become (to invoke Coleridge's poem and M. H. Abrams' classic essay) ${ }^{15}$ an Aeolian harp, humming as the invisibly-fingered agitation of a divine afflatus or breeze wafts through its finely-tuned strings and sets them vibrating in their 'sympathetic harmony'. The imagery of breezes, harp-strings and 'tuned' or 'highlystrung' temperaments is, as Abrams already suggested, one of the unobtrusive but all-pervasive tropes of Romantic lyricism. From the 'blessing in this gentle breeze' (which opens The Prelude) to the wind that sets treetops or cornfields waving at nightfall (in Goethe's Wanderers Nachtlied or Eichendorff's 'Es war als hätt' der Himmel ...'), the formula is all-pervasive, invoking both the power, unknown origin, and invisibility of the poet's inspiration, and the non-cerebral responsiveness of the poet's sensibility. Whatever the particular, specific complexities of these various poets' views on the relation between art and artist, they all celebrate the combination of artlessness in form and responsiveness to the intuited, transcendent meaning of things (a point already made in Maurice Bowra's classic The Heritage of Symbolism, 1951).

Poetry (and art in general) can, in this Romantic view, electrify; much as it results from rapturous inspiration, so too it, in turn, can inspire and enrapture its audience (a point already made by Plato in the Ion dialogue). Romantic art, as a result, can become profoundly rhetorical and propagandistic. The inspirational effect of the Marseillaise was already noted around the battle of Valmy, celebrated as a quasi-magic spell in Jules Michelet's historical description of that episode and echoed in numerous Marseillaise spin-offs - from the painting by Isidore Pils, 'Rouget de Lisle chantant la Marseillaise' $(1849)^{16}$ to the Marseillaise scene in the movie Casablanca. Michelet's rhetoric is worth quoting:

Ronget de Lisle, c'était lui, se précipita de la salle, et il écrivit tout, musique et paroles. Il rentra en chantant la strophe : "Allons enfants de la patrie !» Ce fut comme un éclair du ciel. Tout le monde fut saisi, ravi, tous reconnurent ce chant, entendu pour la première fois. Tous le savaient, tous le chantèrent, tout Strasbourg, toute la France. Le monde, tant qu'il y aura un monde, le chantera à jamais. ${ }^{17}$

And to that immortality (once again corresponding to those death-and-timetranscending lyrical figures of the English Romantics), Michelet adds an explanation of this magic power: the song, in its combination of battle-fury and magnanimity, is more than a mere rhetorical contrivance; it is a direct manifestation of the very soul of the French nation.

Telle était bien alors l'âme de la France, émue de l'imminent combat, violente contre l'obstacle, mais toute magnanime encore, d'une jeune et naïve grandeur; dans l'accès de la colère même, au-dessus de la colère. ${ }^{18}$ 
To be sure, that is just vintage Michelet - his habitual flourish of seeing in the glories of the revolutionary events the glory of France itself; ${ }^{19}$ but precisely in that oft-repeated flourish, Michelet proves himself a Romantic of the Wordsworth, Shelley, and Eichendorff stamp, extrapolating from the actual to the metaphysical, from the evenemential to the transcendent.

That translation of the actual into the ideal also fed into political and constitutional thought. From behind the bloody welter of revolutions and violent regime changes, Michelet sought to discern and salvage an ideal, the spiritual essence of a trans-political France - and with that eminently Romantic programme, he influenced the discourse and rhetoric of French statesmen ever since. It was not just Charles De Gaulle who was mystically inspired by his certaine idée de la France - even in 1842, when the corpse of Napoleon was transported from St Helena to Paris, a political transsubstantiation was operative. When the funeral cortege, after a triumphant, religiously-fervent progress through France, finally arrived at the Invalides, the officer in charge saluted the waiting monarch, LouisPhilippe, and presented a dead emperor to a living king with the words 'Sire, I have brought, as you ordered, the corpse of the emperor'. The confrontation between two regimes (potentially awkward in highlighting the country's constitutional instability and frequent regime-changes) was then defused and taken to an uncontentious level beyond conflict by Louis-Philippe's reply Je le reçois an nom de la France. ${ }^{20}$ The present king and the erstwhile emperor can coexist and cohabit because both represent, each in his reign, something transhistorical and ideal, 'La France'. The situation is, in Novalis's terms, potenziert, the actual selves raised to their higher power. In the process, the figure of Napoleon is also definitively redeemed from party-political contention and, almost literally, canonized as a titanic, world-historical figure - precisely the view which a good few Romantics had always had of him.

Thus, the most abstruse poetical metaphysics of Romantic idealism turns out to have a very real, political application. That had already been recognized by the Prussian general Gneisenau, who, during the years 1810-1813, sought to convince his King to make common cause with popular opinion and turn against the hegemony of Napoleon. The King - dour, pragmatic, and mistrustful of populism - was reluctant to arm his subjects, and dismissed Gneisenau's schemes for a popular insurrection as 'mere poetry'; only to be told by his general that

Religion, Gebet, Liebe zum Regenten, zum Vaterland, zur Tugend, sind nichts anderes als Poesie, keine Herzenserhebung obne poetische Stimmung. Wer nur nach kalter Berechnung handelt, wird ein starrer Egoist. Auf Poesie ist die Sicherheit der Throne gegründet. ${ }^{21}$

'The security of the throne is founded on poetry'. It certainly was founded on little else in those years after the defeats of Jena and Austerlitz, and Gneisenau had judged the mobilizing power of poetic fervour correctly.

The poetry that Gneisenau referred to was probably the verse of Ernst Moritz Arndt, who was a genius at the 'hostile imitation' of French state-building strate- 
gies. Against the Marseillaise, Arndt composed battle verse for the militias of the 1812-1814 anti-Napoleonic wars, most importantly the evergreen Des Deutschen Vaterland. This song put together in a nutshell Arndt's main ideological concerns, which he had spread before in his Geist der Zeit pamphlets: the need for German unity, derived from the twin pillars of a common language and a common morality. The German's fatherland, so the song goes, is more than a mere region, but the entire moral-geographical footprint of the German language area:

\author{
Was ist des Deutschen Vaterland? \\ So nenne mir das große Land! \\ So weit die deutsche Zunge klingt \\ Und Gott im Himmel Lieder singt, \\ Das soll es sein! \\ Das, wackrer Deutscher, nenne Dein! \\ Das ist das Deutsche Vaterland, \\ Wo Zorn vertilgt den welschen Tand, \\ Wo jeder Franzmann heißet Feind, \\ Wo jeder Deutsche heisset Freund - \\ Das soll es sein! \\ Das ganze Deutschland soll es sein !22
}

The link between language as the informing essence of a nation's identity and its territorial footprint - one of the central tenets of ethno-linguistic nationalism found its first and most influential expression in this battle song. I shall return to it at the conclusion of this article. As regards the nationalist passion-building role of poetry, one name beside Arndt's needs to be pointed out: that of Theodor Körner. He had sat at the feet of Friedrich Schlegel in Vienna, joined a volunteer militia in the anti-Napoleonic wars, and fell in battle in 1813. His posthumous collection of poems alternatingly addressing tender feelings and the joys of the soldier's life, Leyer und Schwert ('The Lyre and the Sword'), has fallen out of the canon of German Romantic poetry nowadays, as has the poetry of other patriotic versifiers like Massmann, Rückert, and Geibel, or even Uhland (who is remembered for other things than his patriotic verse); but Körner's impact in the first half of the nineteenth century was enormous. He became the very prototype of the poet-martyr, doing battle and writing verse from one and the same inspiring passion. The impact of Körner reverberates from Mangan and Davis in Ireland to Petőfi in Hungary ${ }^{23}$ to Christo Botev in Bulgaria, and Patrick Pearse in (again) Ireland. The underlying role model of the poet capable of articulating and marshalling his nation's very identity was raised to semi-divine heights in Carlyle's Of Heroes and Hero-Worship, which saw figures like Shakespeare and Dante as indispensable national demigods. Many Romantic poets developed the ambition to become their nation's poetic protagonist by creating its foundational epic: Jan Fredrik Helmers with De Hollandsche Natie ('The Dutch Nation', 1812), France 
Prešeren in Slovenia with his Krst pri Savici ('Baptism on the Savica', 1836), Eduardo Pondal in Galicia with Os Eoas, ('Children of the Sun', unfinished), Runeberg in Finland with Elgskyttarne ('The Elk hunters', 1832) and of course Adam Mickiewicz with his various Polish-themed epic poems. Even later, Frédéric Mistral's Occitan Mireio (1859) and Jacint Verdaguer's Catalan L'Atlàntida (1877) can be considered a poet's attempt to forge (as James Joyce ironically phrased it) 'in the smithy of his soul the uncreated conscience of his race'. That urge also expressed itself in the more modern genres of the historical drama and novel, and the 'instrumentalized text edition', of which some more will be said later.

This idea that verse tapped the soul of the nation and brought its transcendent, soul-stirring glory closer to society carried over into the field of music, which was considered to have a uniquely 'inspiring' potential. The Leyer und Schwert lyrics, set to choral music by the young Carl Maria von Weber in 1814, marked the start of that composer's 'national' prestige and helped to mark out his debut opera Der Freischütz (1821), with its folk-vernacular topic, as a 'national German' work. Thenceforth, Romantic music has such close interconnections with nationalism that the point need hardly be laboured; Glinka and his Russian successors, Chopin, Liszt, Smetana, and Wagner may suffice as indices. Like the Romantic poets, the Romantic composers increasingly cultivated an artistic stance of inspiration and disregard for established formal conventions, exploring new harmonies and new musical forms such as the rhapsody or the symphonic poem. Like the poets, they turn to the vernacular, adopting musical genres, modes and stylistic features from outside the established classical repertoire: mazurka, hornpipe, csardas or jota; Gypsy music with its augmented seconds, folk melodies with their Doric or Mixolydian modes, drone bass lines and parallel fifths. And as in the case of the poets, the combination of vernacular expressions and sublime inspiration turn composers from mere virtuosi into the inspired mouthpieces and champions of their nation. ${ }^{24}$

Here, too, what started out as an artistic programme became an accepted nation-building instrument. By the 188 os the nationalistic fervour that music could inspire was invoked as a matter of received wisdom - Albert, Prince of Wales (the future Edward VII), mentioned in a speech 'those emotions of patriotism which national music is calculated so powerfully to evoke ${ }^{32}$. He is still proved right, year after year, at the Last Night of the Proms, with its flag-waving performances of 'Land of Hope and Glory', 'I Vow to Thee, my Country', and 'Jerusalem' - all of them (slightly belated) answers to the Marseillaise.

\section{Volksgeist, Historicism, Medievalism}

The transcendental essence which poets and historians tried to extrapolate from the transient incidents of material reality had, in a national context, been given a name by 1805: it was called Volksgeist. The term originated in the legal arguments of scholars like Hegel and, especially, Friedrich Carl von Savigny, who resisted the imposition of a Napoleonic code on German states. In Savigny's view, it was 
a travesty to have a millennial heritage replaced by a merely instrumental set of regulations devised by an ad-hoc assembly of bickering politicians. Savigny became the foremost proponent of an organicist notion of law (which also took in the older views as put forward by Montesquieu) that each nation engendered its own proper legal system - as much as it had its own language. In due course, Savigny (who lived from 1779 until 1861) was to become one of the great legal statesmen of post-Napoleonic Prussia. But in pre-1813 Marburg, part of the newfangled Kingdom of Westphalia ruled by a minor Bonaparte, he was as yet a reserved academic, muttering through clenched teeth in the privacy of his study. In claiming that a law system was the direct expression of a nation's specific mentality, Savigny was the first in the German language to give currency to the notion of Volksgeist. ${ }^{26}$

Interestingly, this reliance on a national psyche to identify cultural traditions and specificities also meant that Savigny was a true historicist - in fact, the very founder of the 'historical school' in jurisprudence. Law, to Savigny, was an evolving moral corpus as much as it was an organically collective one - it developed as the nation developed across the centuries, and it should therefore be seen as an historical accumulation rather than as a mere set of rules and guidelines.

In formulating this link between national essentialism, organicism, and historicism, Savigny's ideas summarized the fundamental European refusal of the Napoleonic, technocratic view of the state. Edmund Burke had similarly rejected the French Revolution's reliance on society as a set of interactive obligations (the Rousseauesque 'social contract'), and, like Savigny, had pointed out that nations cannot be adequately defined in purely synchronic terms, necessitating also a diachronic perspective. In his Reflections on the Revolution in France, Burke had written, famously:

Society is indeed a contract. Subordinate contracts for objects of mere occasional interest may be dissolved at pleasure; but the state ought not to be considered as nothing better than a partnership agreement in a trade of pepper and coffee, calico or tobacco, or some other such low concern, to be taken up for a little temporary interest, and to be dissolved by the fancy of the parties. It is to be looked on with other reverence; because it is . . a partnership in every virtue and in all perfection. As the end of such a partnership cannot be obtained in many generations, it becomes a partnership not only between those who are living, but between those who are living, those who are dead, and those who are to be born. Each contract of each particular state is but a clause in the great primeval contract of eternal society, linking the lower with the higher natures connecting the visible and invisible world, according to a fixed compact sanctioned by the invisible oath which holds all physical and all moral natures each in their appointed place. ${ }^{27}$

A trans-generational contract, 'not only between those who are living, but between those who are living, those who are dead, and those who are to be born': this very argument is what Fichte unfolded in his Reden an die deutsche Nation of 1808. Germany cannot be reformed on a French model because that would break 
the diachronic continuity and indeed the transcendent essence of what constitutes the nation.

As the here-and-now was being disrupted to its very foundations by the Napoleonic avalanche of revolutionary changes, innovations and abolitions, intellectuals sought stability in the diachronic continuities and traditions: historicism, the anchoring of the present in the past. ${ }^{28}$

The impact of Savigny's particular brand of national-organicist historicism, which sees all things as the end-products of a growth process, is best illustrated with reference to his most famous pupil. As law professor in Marburg, Savigny served, for a while, as mentor to a bright young law student, whom he trained in the jurisprudential craft of paleography - the study of ancient documents and their provenance, of old types of handwriting and of obsolete forms of the language. At this time, the study and source-criticism of medieval documents was almost the exclusive preserve of legal historians such as Savigny; medieval literature was as yet merely an entertaining fancy for antiquaries and amateurs. This young scholar thus trained by Savigny was bookishly inclined and even followed his master as an assistant, when Savigny went to Paris to consult sources in the Parisian libraries and archives. The young man was none other than Jacob Grimm. ${ }^{29}$

Himself the son of a lawyer (who had died early, leaving him an impoverished semi-orphan), Grimm had enrolled at Marburg in order to prepare for a career as a public official through the traditional means of a law degree. Later on he was to choose differently, having meanwhile discovered, among the old documents Savigny introduced him to, the literary riches of the Minnesänger and Reinhart Fuchs. Even so, he was to remain close to Savigny for the rest of his life and applied to his study of cultural material precisely that historicist organicism that he had learned from his legal mentor and from the craft of jurisprudential source criticism. $^{30}$

Savigny introduced Jacob Grimm, and also Jacob's shy brother Wilhelm, to a set of literary amateurs whose social gatherings he frequented. This was the socalled 'Bökendorf Circle', so named after the country seat of the baronial family Von Haxthausen. The young Haxthausens, August and Werner, had cultural, literary and national interests and received like-minded people (such as their cousin Annette von Droste-Hülshoff) in what became a regular network. The central node in this network was occupied by Clemens Brentano, who since the beginnings of his Göttingen student days had struck up a close friendship with Achim von Arnim, who married Brentano's sister Bettina in 1811. Brentano's other sister Kunigunde became the wife of, again, Savigny.

It was through these associations that the Grimm brothers, as Savigny's protégés, came to attend gatherings at Bökendorf. They were also involved in the collection of folksongs that formed the Bökendorf Circle's chief literary pleasure that was to culminate in the collection Des Knaben Wunderhorn in 1806-1807. Edited by Arnim and Brentano, this prototype of all Romantic folksong collections was really the collective effort of the entire Bökendorf Circle. Indeed the Grimms' own collection of fairy tales (the epoch-making Kinder- und Hausmärchen, which 
appeared in 1812 and included material contributed by the Arnims, Brentanos, Haxthausens and Droste-Hülshoffs) may be seen as a prose spin-off of the Wunderhorn. ${ }^{31}$ But there was a difference. Whereas the folk material collected in the Wunderhorn was meant to appeal to sentimentally inclined readers, who wanted to dip into the naïve, but charming verses of simple country folk, the interest of Grimm's folk- and fairy tales was different. The Grimms sensed that such tales constituted the oral remains of an older, now-vanished system of supernatural beliefs and sagas of the German nation. For the Grimms, pupils of Savigny, the interest of these tales was historicist and anthropological, a window on the primitive mentality of the German nation in its infancy. And so we can trace, from the Wunderhorn (1806) to the Märchen (1812), and thence to the Grimms' Deutsche Sagen (1816) and Jacob Grimm's Deutsche Mythologie (1835) a progress from sentimentalism to philological historicism, and from a dilettante literary interest to hard-nosed academic scholarship.

At the same time, Grimm developed his linguistic skills, coming to the formulation of 'Grimm's Laws' in his Deutsche Grammatik around 1820. Again, we can see this as the application of Savigny's legal historicism to cultural topics: Grimm looked at language, not as a fixed, closed system, but as a process in a continual state of development, where each phenomenon was to be understood as the product of an evolutionary dynamics. Das Sein aus dem Werden begreifen - to understand what is in terms of how it came to be - was a methodological historicism for which Grimm always acknowledged the mentorship of Savigny. ${ }^{32}$

For Grimm and the generations of Germanisten whom he inspired, all the various specialisms they deployed (folklore studies, linguistics, history, literature, and jurisprudence) came together in the overriding agenda to understand the nature of the German nation, its origins and national psyche. Much as astrophysicists nowadays seek to understand the universe by taking their observations back to conditions as close as possible to the Big Bang, so too the historicism of the Grimms led them back towards the most ancient, heroic, epic-collective moments in the nation's history. There, in the tribal beliefs, cults, dialects, and lays, before native authenticity was addled by Roman, Christian, and foreign influences, lay the moment when the German nation enjoyed a pristine cultural authenticity, when priests, bards, and judges were essentially serving one and the same purpose: to articulate what it meant to be properly German. That is what the logos in philology stands for: culture, in the philological view, was an act of national self-creation by self-articulation. Not for nothing does the Grimms' massive Deutsches Wörterbuch carry, as an epigraph, the opening line of the Gospel according to John: Im Anfang war das Wort - in the beginning was the Word. ${ }^{33}$

The nationalistic applicability of this type of philology was enormous - and, in the German case, notorious. ${ }^{34}$ To understand the nation's cultural and literary track record was a national enterprise, witness this appeal of the great French medievalist Gaston Paris for a text society in the year 1875 (overshadowed by the recent defeat of $1870-1871)$ : 
We appeal to all those who love the eternal France, to all those who feel that a people which repudiates its past is ill prepared for its future, and to all those who know that a national consciousness is only fully alive when it links together, in a profound solidarity, the present and the bygone generations.

And two years later, he came back to the idea of a philological historicism as a national imperative, calling on the support of those who felt that

[L] a piété envers les aïeux est le plus fort ciment d'une nation, de tous ceux qui sont jaloux du rang intellectuel et scientifique de notre pays entre les autres peuples, de tous ceux qui aiment dans tous les siècles de son histoire cette "France douce" pour laquelle on savait déjà si bien mourir à Roncevaux..$^{35}$

\section{The National Past and the Contemporary State}

The reference to Roncesvalles at the end of Paris's quote is more than just a philologist's invocation of the Chanson de Roland, with its heroic-chivalric celebration of a noble defeat on behalf of la douce France. It also alerts us to the fact that Romantic historicism had, in the century after Ossian and the first modern edition of the Edda, furnished all self-styled nations of Europe with something that was now called a 'national epic', and that this constituted the philologists' main claim to social recognition. The first edition of the Chanson de Roland had come out in 1836 , and it was in the post-1871 context that the text became a symbolic classic for a revanchist France. A similar nation-building function in times of defeat had propelled the canonicity of the Nibelungenlied in Germany, first given a modern edition in 1806. It was in a review of this edition in 1807 that Wilhelm Grimm called it a 'National-Epos', probably the first time that term was used. (Previously, the genre epic referred exclusively to texts in the classically transnational canon, like the Iliad or the Aeneid).

Indeed, most of these national classics which are now habitually placed in the opening chapters of literary histories, as the originary starting point of literary traditions, were published in the Romantic decades: Besides the Nibelungenlied and the Chanson de Roland, there were the Russian Lay of Prince Igor (1800), the Dutch Caerle ende Elegast (1832), Beowulf (1815) and the tale of Deirdre (1808, the first published fragment of the Gaelic Táin Bó Cuailgne). ${ }^{36}$

Here, as in the case of Volksgeist historicism, such literary re-launchings involve at the same time a sense of a reconnection with ancient roots and (the national literature as an enduring and informing continuity), and a new sense of historical dynamics (literature as a continual growth process). The latter aspect was explored most influentially in the lecture series on literature held by the Schlegel brothers, especially Friedrich's Vienna lectures of 1810, published in 1813. What Schlegel delivers is in fact an application of Savigny's organicism to literature: literature is defined as the collective imagination and memory of a national community, through which it articulates itself into higher states of historical awareness and powers of cultural self-reflection. As such, it grows from 
primitive origins in a continuous development, along with the nation's historical experiences and moral track record. Much as, for Grimm, the nation is the categorical unit of language and culture, so for Schlegel the nation with its own national language becomes the categorical unit for literature - a sharp departure from earlier literary-historical approaches, for whom language of expression or the nationality of the author had been incidental qualities rather than categorical determinants, and for whom 'development' did not have the overtones of organic growth-processes that it had after Schlegel. The idea that literature is a dynamic process rather than a condition or a corpus echoes perhaps, that first gnomic usage of the qualification 'progressive' in Schlegel's famous earlier, 1798 definition of Romantic poetry as 'progressive-universal'.

The sense that literature also forms a mental continuum between the nation's present and its past is no less important. For Grimm, reading ancient epic works was a form of mental time-travel, in which the reader had to transport himself back into 'wholly vanished conditions'; the very definition, perhaps, of literary historicism.

Unter den drei dichtungsarten fällt zu beurtheilen keine schwerer als das epos, denn die lyrische poesie aus dem menschlichen herzen selbst anfsteigend wendet sich unmittelbar an unser gemüt und wird aus allen zeiten $z u$ allen verstanden; die dramatische strebt das vergangne in die empfindungsweise, gleichsam sprache der gegenwart umzusetzen und ist, wo ibr das gelingt, in ibrer wirkung unfehlbar. ... um die epische poesie aber steht es weit anders, in der vergangenheit geboren reicht sie aus dieser bis zu uns herüber, obne ibre eigne natur fahren zu lassen, wir haben, wenn wir sie genieszen wollen, uns in ganz geschwundene umstände zu versetzen. (Missing capitalization sic.).

By the same token, ancient texts were points of ancestral reconnection, living manifestations of that trans-generational contract which, in the historicist view, constitutes the nation's enduring identity. This is why the reprinting of ancient texts, salvaging them from the unread limbos of neglected archives and bringing them into the light of the public sphere by means of printed publication, was such a core concern for Romantic philologists.

That philological recycling reached out into adjacent fields. Where ancient manuscript were unavailable, scholars turned to orally transmitted epic works instead - most famously, in the edition of the oral epic from the Balkans - Hasanaginica and the collections of Vuk Karadžić - but also in the Grimm-inspired collections of tales and verse in the Baltic, in Scandinavia, In Russia and the Ukraine. ${ }^{38}$ In many cases, the materials thus collected were given 'epic' (that is to say: heroic and national-foundational) status, and in many cases such 'instrumentalized editions' tread a thin line between authenticity and forgery. The prototype of this type of endeavour, Macpherson's Ossian, is already a notorious case in point, and severe authenticity doubts have surrounded similar editions such as Lönnrots Kalevala or La Villemarqués Barzaz Breiz. Vaclav Hanka's edition of a medieval Bohemian manuscript heroically extolling the Czechs' resistance against the Germans was based on a forgery which he himself had fabricated; and debates sur- 
round, to this very day, the actual provenance and authenticity of the Lay of Prince Igor. ${ }^{39}$ Doubtful as the underlying methodology may have been, the nationalist cultural impact of these texts has been none the smaller, either in La Villemarqué's Brittany, in Lönnrots's Finland, or in the Russia that saw Prince Igor turned into Borodin's national opera.

A hugely important genre that may to some extent be considered a spin-off of philological historicism was the historical novel in the Walter Scott mode. ${ }^{40}$ Scott was himself, of course, a textual editor of note (e.g. his Minstrelsy of the Scottish Border and the Sir Tristram romance by Thomas the Rhymer) and in some of his novels (for example, Quentin Durward) presents the fictional tale itself as a quasi-edition of a manuscript found in an attic. That frame-narrative conceit of the 'found manuscript', a favourite of the genre of the Gothic romance and, subsequently, of the historical novel down to Umberto Eco's The Name of the Rose, rises to prominence in these decades, when in fact a lot of manuscripts were being found in attics and in secularized monastic libraries all over Europe. Certainly the one overwhelming reason for Scott's huge success was the historicist appeal of his novels: the way they could transport their readers back into wholly vanished conditions' (to recall Grimm's phrase), the way they brought the past back to life (as the telling phrase was with many readers, not least among envious historians). Bringing the past back to life: that was not merely a private reading sensation, but the very definition of what romantic historicists were aiming to do.

As is widely attested, Scott's powers of evoking the past through the literary imagination caused great envy among the historians of his generation (Macaulay, Thierry, Michelet, and all their nation-building followers in Central and Eastern Europe); ${ }^{41}$ that envy is, in fact, what marks these historians out as 'Romantic historians' - that, and their transcendental idealism noted earlier on, as well as their tendency to cast the nation-at-large as the protagonist of their historical narratives. ${ }^{42}$

Bringing the past back to life also spread from Scott to other fields besides history-writing: most importantly, the visual arts. History painting, an established and prestigious pictorial genre ever since the establishment of the classical art academies, underwent a vernacular turn and 'went national' in these decades. Originally, the themes for academic history paintings were restricted to the canon of biblical and classical antiquity; and this had begun to change in the second half of the eighteenth century, first in the art that glorified the dynastic roots of monarchs and then in the art that celebrated the hero figures of medieval chivalric and early-modern Europe, such as Joan of Arc. Initially, the non-classical repertoire of romantic history painting was not particularly nationalized - the 'troubadour' paintings of France could as easily take themes from English, Italian or Spanish medievalism as from French. ${ }^{43}$ However, after the 1820 s we can see a definite penchant among Romantic history painters for topics from the nation's own history (although the themes from biblical and classical antiquity remain strongly present). ${ }^{44}$ 
The aim to 'transport the audience into the past' may be responsible for the tendency for history painting to use increasingly large canvases and to cover entire walls with huge shock-and-awe scenes into which onlookers can immerse themselves. ${ }^{45}$ The art of the historicizing mural is linked to the newly established Düsseldorf Art Academy and was used to render a more complete illusion of age and authenticity to new, or newly restored, building in the nineteenth century. Many of those buildings, whose interiors were covered in historicist murals (by artists like Rethel, von Schwind, Wislicenus), were themselves built in a Puginesque neo-gothic style or historicist style: the Amsterdam Rijksmuseum, the Neuschwanstein castle in Bavaria, the city hall of Antwerp; among the restorations which involved extensive mural decoration were Hohenschwangau, the Goslar Imperial Manor in Prussia-annexed Hanover, the city hall of Aachen, and the Wartburg. The fashion persisted (like Romanticism itself) until the turn of the century: witness Akseli Gallen-Kallela's murals, on themes from the Kalevala, for the Helsinki National Museum, and Carl Larsson's fresco 'Midvinterblod' for the Stockholm National Museum - both, again, places dedicated to 'bringing the past to life' and 'encapsulating the nation's identity'. The huge series of historical paintings by Alphonse Mucha, The Slavic Epos, is perhaps the last flourish of the genre, and also a good example of the merger between the 'epic' mode of romantic historicism which the visual arts borrowed from romantic philologists and novelists. (The tradition survived, in the twentieth century, in the new genre of the historical spectacle movie, which often involved screen adaptations of nineteenth-century post-Walter Scott historical novels.)

We see how Romantic historicism can freely move between media and cultural fields: from philological antiquarianism to fictional narrative and the visual arts. ${ }^{46}$ Its prime point of overlap, Wagner's notion of the operatic Gesamtkunstwerk, indicates that it is anything but mere escapism or consumerism, but profoundly informed by the politics of celebrating the nation. The 'monumental' size of history paintings and their public display locations also indicates their 'monumental' function in rendering the nation's past a collective point of reference for the modern-day state. Academic art flourished most egregiously in the many commemorative monuments that were thickly scattered among the public places of the European city-spaces, amounting to what has been variously described as statuomanie or Denkmalwut. ${ }^{47}$

What is equally striking is how these national motivations were applied in highly transnational fashions and vogues. Scott's novels had an incalculable inspiring effect on national movements everywhere. For the Scottish readership, they affirmed that Scotland was not merely a subjugated periphery of the British state, but something which - from having a past of its own - derived a legitimate identity of its own. ${ }^{48}$ While Scott placed his historicism in the service of a Scottish-accommodated Great Britain (as the notorious management of George IV's Edinburgh visit shows), ${ }^{49}$ the impact of his novelistic formula elsewhere in Europe was to galvanize historicist nationalism among all subaltern nationalities - Flemish, Polish, Hungarian, Baltic, etcetera. In the course of the century, 
'having a history of one's own' came to rank alongside 'having a language of one's own' as the main entitlement to a properly national (as opposed to regional) identity..$^{50}$ (Conversely, the idea of regionalism was predicated on the very absence of historicity, on the idea of timelessness, static traditionalism and rustic idyll.)

\section{Dialectics, Restoration, and Cultural Geopolitics}

Ironically, Scott's novels are in fact the very opposite of epic. The message of an epic is to glorify hard-won victory or heroism-in-defeat. Such epic endings, in the mode of the Nibelungenlied, Beowulf and the Chanson de Roland, were in fact used by Scott's followers elsewhere in Europe, like Hendrik Conscience in Flanders and Henryk Sienkiewicz in Poland; ${ }^{51}$ but Scott himself rarely opted for that type of narrative resolution. His plotline typically places powerless protagonists in a national crisis between opposing forces, and resolves the narrative by letting the protagonists survive into a future in which ancient hatreds will be laid to rest. Whereas Conscience's novels De leeuw van Vlaanderen and De Kerels van Vlaanderen, and Sieniewcz's 'Trilogy' or Krzyzaci, exhort the reader to follow the inspiring ancestral example of resisting and defeating the foreigner, Scott's novels suggest that it is wiser to let bygones be bygones.

The resolution that Scott holds out in his novels is remarkably close to the Hegelian notion of Aufhebung, with its threefold meaning of abolishing the past, raising it to a higher level and storing it away in a safe place. Aufheben is exactly what Scott does with the past: the Jacobite Rebellion of 1745 (in Waverley), the Norman-Saxon divide (Ivanhoe), or the Covenanting wars (Old Mortality), are laid down ad perpetuam rei memoriam, salvaged from oblivion, and at the same time shown to have been surmounted, to have become a matter of history, without partisan-antagonizing power in the present - something to be respected, but neither to be repressed nor to be revived.

What Scott and Hegel share is a new sense of historical development: a dialectical one, where history moves through the alternation of conflict and resolution. That movement was also instinctively grasped by Goethe, who repeatedly compared it to the opposing, alternating movement of contraction and expansion, diastolics and systolics, which between them form a heartbeat. Goethe based the entire dialectics of his Faust on it: the play's forward impulse is generated by Faust's insatiable thirst for knowledge and Mephistopheles's 'everlasting nay'. If Romantic poetry is 'progressive' (in Schlegel's usage of the term progressive Universalpoesie i.e. ongoing, unceasingly proliferating), then its impulse lies in this desire to explore the unaccustomed rather than to acquiesce in applying the norm. This, of course is fundamentally different from the poetics of classicism, and of the Enlightenment's view of historical development as causal, linear, and progressive.

Both Romanticism and nationalism are characterized by a combination of dynamic progressivism and nostalgia for permanence. The dialectic idea that historical progress is never linear but a conflict-driven process of constantly re- 
negotiating one's relationship with, and continuation of, the past, appears to be a common denominator, evinced by historians, philosophers, artists, and writers. What is more, the 'past' which in these Romantic decades becomes a rear-view mirror for the dynamism of progress is almost invariably seen as, specifically, a national one.

Nationalism is, of all the great political doctrines of the nineteenth century, perhaps the most idealistic one in that it derives its political agenda, not from social or practical considerations of state interest, power, or wealth, but from the ideal-typical abstraction of the 'nation' and its essential character or Volksgeist. This national essence can be understood or intuited from its expressions in the collective history, the subsisting vernacular culture (always seen as a remnant from the primordial past), or its language. And from those abstractions, a very specific, concrete agenda is derived concerning the empowerment of the 'nation' in the state's constitution and, more importantly, the geographical outlines of that state. Nationalism typically will try to align the borders of the state with the cultural footprint of the nation.

To be sure, there had been earlier, isolated attempts to rationalize cultural differences in administrative divisions; but this is almost negligible compared to the all-dominant tendency to define the nation by its language and history, and to define the state's geography by its constituent nationality. Given the fact that in the Romantic decades most states were multi-ethnic monarchies, this necessarily engendered an enormous discourse of cultural geopolitics. The principles were laid down by intellectuals like Arndt, whose song 'What is the German's Fatherland' answers the question raised in its opening line with recourse to the spread of the German language. That line of reasoning was implicitly also proclaimed in Hoffmann von Fallersleben's 'Deutschland, Deutschland über alles', which celebrates an ideal, yet-to-be-realized Germany stretching beyond political frontiers from the Meuse to the Niemen and from the Belt to the Adige. The conflicts and wars that this linguistic geopolitics triggered in all German borderlands (indeed, from the Meuse to the Niemen and from the Belt to the Adige!) are notorious, as is the application of linguistic geopolitics in other culturally mixed areas of Europe, from the Basque country to the Balkans and from Ulster to the Baltic. Carried by the transnational spread of Romanticism at large, Romantic nationalism allowed all vernacular cultures in Europe to raise claims to recognition in one form or another - and while these claims were in the first instance raised in the academic centres of learning and the metropolitan centres of power, they were soon mapped onto the provincial borderlands, which accordingly became an enfer des autres. Romantic nationalism challenged the elite universalism of the Enlightenment, but in the process forgot Herder's cultural relativism and instead established a shooting gallery of essentialist, introspectively self-celebrating, mutually intolerant vernaculars.

In the preceding pages, I have attempted to weave a skein of connections in three dimensions: between the politics of nationalism and the poetics of Romanticism; between intermedially related cultural fields and media of artistic and 
intellectual expression; and between different countries and societies communicatively linked by manifold cultural transfers. In the process I have also shuttled back and forth between my three thematic strands: linguistic essentialism and the vernacular turn; romantic historicism; and the poetics of transcendence and inspiration. In doing so, I hope to have demonstrated, not just the plurality, but also the density of the interconnections between Romantic and nationalist thought in early-nineteenth-century Europe. If there is such a thing as Romantic nationalism, we must conceive of it, not as a lump of facts or a cloud of semantics, but as a knot, a tight tangle, a node in the mycelium of intellectual and cultural developments. Romanticism and nationalism, each with their separate, far-flung root-systems and ramifications, engage in a tight mutual entanglement and Wablverwandschaft in early-nineteenth-century Europe; and this entanglement constitutes a specific historical singularity. We can give this singularity a name: Romantic nationalism. And we may understand that to mean something like: the celebration of the nation (defined in its language, history, and cultural character) as an inspiring ideal for artistic expression; and the instrumentalization of that expression in political consciousness-raising. 


\section{Notes}

1 In what follows, I want to steer clear of the vexed finesses of periodization and typology that affect the discussions both of Romanticism and of nationalism. In selecting examples of Romantic writers, artists, intellectuals or cultural products, I follow the broadly accepted canon, fanning out from literary activities in 1790s Germany and Britain to other media and to European areas over the next decades; in selecting examples of nationalism, I follow the same spatiotemporal frame, as set out in my National Thought in Europe: A Cultural History (Amsterdam: Amsterdam University Press, 2008). Two further prolegomena: I cite classic Romantic 'soundbytes' merely as illustrative point of recognition requiring no specific source-reference; and throughout the text I rely, without specific source-referencing in each instance, on cases made in greater detail in a few earlier articles: 'Nationalism and the Cultivation of Culture', Nations and Nationalism 12, no. 4 (2006): 559-78; 'From Bökendorf to Berlin: Or, How the Past Changed in Jacob Grimm's lifetime', in Free Access to the Past: Romanticism, Cultural Heritage and the Nation, ed. L. Jensen, J. Leerssen and M. Mathijsen (Leiden: Brill, 2008), 55-80; De Bronnen van het Vaderland: Taal, Literatuur en de Afbakening van Nederland 1806-1890, 2nd ed. (Nijmegen: Vantilt, 2011); 'Viral Nationalism: Romantic Intellectuals on the Move in Nineteenth-Century Europe', Nations and Nationalism 17, no. 2 (2011): 257-71; 'The Rise of Philology: The Comparative Method, the Historicist Turn and the Surreptitious Influence of Giambattista Vico', in The Making of the Humanities, ed. R. Bod, J. Maat \& T. Weststeijn, vol. 2, From Early Modern to Modern Disciplines (Amsterdam: Amsterdam University Press, 2012), 23-35.

2 Hans Kohn, 'Romanticism and the Rise of German Nationalism', Review of Politics 12 (1950): 443-70. To be sure, the case of Germany stands out (and will be referred to in this article as well), since the interconnections between the Romantic Movement and the concurrent antiNapoleonic Befreiungskriege were always a matter of record; cf. Andries David Verschoor, 'Die ältere deutsche Romantik und die Nationalidee', doctoral thesis (Amsterdam: H.J. Paris, 1928), Klaus Siblewski, Ritterlicher Patriotismus und Romantischer Nationalismus in der Deutschen Literatur 1770-1830 (München: Fink, 1981) and Wolfgang Müller-Funk and Franz Schuh, eds., Nationalismus und Romantik (Vienna: Turia + Kant, 1999).

3 Thus in surveys such as Gustave Charlier, Le Mouvement Romantique en Belgique (1815-1850), vol. 2, Vers un romantisme national (Bruxelles: Palais des Académies, 1959), or Jean Plumyène, Histoire du Nationalisme, vol. 1, Les Nations Romantiques: Le XIXe Siècle (Paris: Fayard, 1979).

4 Joan S. Skurnowicz, Romantic Nationalism and Liberalism: Joachim Lelewel and the Polish National Idea (New York: Columbia University Press, 1981); Andrzej Walicki, Philosophy and Romantic Nationalism: The Case of Poland (Oxford University Press, 1982); Serhiy Bilenky, Romantic Nationalism in Eastern Europe: Russian, Polish, and Ukrainian Political Imaginations (Stanford: Stanford University Press, 2012); Wilhelm Baum, Urban Jarnik: Romantik, Nationalismus und Panslawismus in Kärnten (Klagenfurt-Wien: Kitab, 2009); Balázs Trencsényi \& Michal Kopeček (eds.), Discourses of Collective Identity in Central and Southeast Europe, vol. 2, National Romanticism: The Formation of National Movements (Budapest: CEU Press, 2007). My own National Thought in Europe contains some ideas and examples in this direction which will be picked up in the present article.

5 Roger D. Abrahams, 'Phantoms of Romantic Nationalism in Folkloristics', Journal of American folklore 106 (1993): 3-37; Oscar Julius Falnes, National Romanticism in Norway (New York: Columbia University Press, 1968); Barbara Miller Lane, National Romanticism and Modern Architecture in 
Germany and the Scandinavian Countries (Cambridge: Cambridge University Press, 2002); Katie Trumpener, Bardic Nationalism: The Romantic Novel and the British Empire (Princeton, NJ: Princeton University Press, 1997).

6 In nationalism studies, an inspiring example to that effect is Anne-Marie Thiesse's La Creation des Identités Nationales (Paris: Seuil, 1992), which admirably manages to analyse culture both as an agency and as a historical dynamics.

7 Maurizio Viroli, For Love of Country: An Essay on Patriotism and Nationalism (Oxford: Clarendon, 1995).

8 Hans Aarsleff, The Study of Language in England, 1780-1860 (Princeton, NJ: Princeton University Press, 1967); Sylvain Auroux, E. F. K. Koerner, Hans-Josef Niederehe, and Kees Versteegh, eds., History of the Language Sciences. An International Handbook on the Evolution of the Study of Language from the Beginnings to the Present, 2 vols. (Berlin: De Gruyter, 2000-2001); Mary Anne Perkins, 'Romantic Theories of National Literature and Language in Germany, England, and France', in Nonfictional Romantic Prose: Expanding Borders, ed. S. P. Sondrup and V. Nemoianu (Amsterdam: Benjamins, 2004), 97-106; Pierre Swiggers and Piet Desmet, 'Histoire et Épistémologie du Comparatisme Linguistique', in Le Comparatisme dans les Sciences de l'Homme, ed. G. Jucquois and C. Vielle (Paris / Louvain-la-Neuve: De Boeck, 2000), 157-208.

9 Carmen Alén Garabato, L'Éveil des Nationalités et les Revendications Linguistiques en Europe (Paris: L'Harmattan, 2000); Petra Broomans et al., eds., The Beloved Mothertongue: Ethnolinguistic Nationalism in Small Nations; Inventories and Reflections (Leuven: Peeters, 2008); Otto Dann, 'The Invention of National Languages', Proceedings of the British Academy 134 (2006): 121-33.

10 Cf. my Remembrance and Imagination: Patterns in the Literary and Historical Representation of Ireland in the Nineteenth Century (Cork: Cork University Press, 1996).

11 Despite Kohn's now-notorious tendency to schematize 'good' western-democratic nationalism versus bad eastern-despotic nationalism, his Pan-Slavism, its History and Ideology, 2nd. ed. (New York: Vintage, 1960) is still unsurpassed as a conspectus of the intellectuals, writings and events.

12 Miroslav Hroch, Die Vorkämpfer der Nationalen Bewegung bei den Kleinen Völkern Europas. Eine Vergleichende Analyse zur Gesellschaftlichen Schichtung der Patriotischen Gruppen (Praha: Universita Karlova, 1967).

13 In the original: 'Das Unendliche umgibt den Menschen, das Geheimnis der Gottheit und Welt'.

14 'Romanticizing something is to raise its exponent to a higher power. The lower self becomes its higher self, much as we ourselves are such an exponential succession. . . . If I give the banal a higher sense, give the well-known a mysterious aspect, vest the familiar with the dignity of the unfamiliar, then I romanticize it; and conversely so, when I logarithmically bring down the higher, unknown, mystical and infinite into a common expression'. Ernst Behler, Frübromantik (Berlin: Walter de Gruyter, 1992), 162.

15 M. H. Abrams, 'The Correspondent Breeze: A Romantic Metaphor', in Id., The Correspondent Breeze: Essays on English Romanticism (New York: Norton, 1986).

16 For a high-definition photograph of the work, go to http://en.wikipedia.org/wiki/File:Pils_-Rouget_de_Lisle_chantant_la_Marseillaise.jpg

17 'Rouget de Lisle, for he it was, burst into the room, wrote it all down, music and words. $\mathrm{He}$ returned singing the stanza 'Come, children of the fatherland!' It was like a burst of light from the sky. Everyone was moved, excited, all recognized the song even as they heard for the first time. They all knew it, they all sang it, all of Strasbourg, all of France. The world, for as long as 
there will be a world, will forever sing it'. Cf. Michel Vovelle, ' "La Marseillaise” ', in Les Lieux de Mémoire, ed. Pierre Nora, vol. 1 (Paris: Gallimard, 1997), 107-52.

18 'Such indeed was the soul of France, moved by imminent combat, violent against its obstacle, yet wholly magnanimous, with a youthful and naive grandeur; even at the height of anger, above anger'. Cf. Ann Rigney, The Rhetoric of Historical Representation: Three Narrative Histories of the French Revolution (Cambridge: Cambridge University Press, 1990). Jean Tulard, 'Le Retour des Cendres', in Les Lieux de Mémoire, ed. Pierre Nora, 3 vols. (Paris: Gallimard, 1997), 1729-56. 'Religion, prayer, love of the ruler, of the fatherland, or virtue: all that is nothing but poetry. There is no enthusiasm without a poetic disposition. If we act only from cold calculation, we become rigid egoists. The security of the throne is founded on poetry.' Quoted in Leerssen, National Thought in Europe, 118.

22 'What is the German's fatherland? / At last do tell me where it lies! / As far as the German tongue is heard, / singing the praises of God on high, / That it must be! / That, bold German, you can name yours! // That is the German fatherland: / Where scorn destroys all French foppery / Where every Frenchman is called foe / And every German is called friend, / That it must be! / Germany entire it must be!' For the German original, see Gilbert Krebs and Bernard Poloni, Volk, Reich und Nation: Texte zur Einheit Deutschlands in Staat, Wirtschaft und Gesellschaft 1806-1918 (Asnières: Presses de la Sorbonne Nouvelle et CID, 1994), 31.

23 Csilla Erdödy-Csorba, ed., Europäische Romantik und Nationale Identität: Sándor Petôfi im Spiegel der 1848er Epoche (Baden-Baden: Nomos, 1999).

24 Celia Applegate and Pamela Potter, eds. Music and German National Identity (Chicago: University of Chicago Press, 2002); Philip Vilas Bohlmann, The Music of European Nationalism: Cultural Identity and Modern History (Santa Barbara, CA: ABC-Clio, 2004); Benedikte Brincker, 'The Role of Classical Music in the Construction of Nationalism: An Analysis of Danish Consensus Nationalism and the Reception of Carl Nielsen', Nations and Nationalism 14, no. 4 (2008): 684-99; Benjamin Curtis, Music Makes the Nation: Nationalist Composers and Nation-Building in NineteenthCentury Europe (Amherst, MA: Cambria, 2008); Carl Dahlhaus, 'Die Idee des Nationalismus in der Musik', in Id., Zwischen Romantik und Moderne. Vier Studien zur Musikgeschichte des späteren 19. Jahrbunderts (München: Katzbichler, 1974), 74-92.; Olympia Frangou-Psychopedis, I Ethniki Scholi Mousikis: Provlimata Ideoloyias (Athens: Idryma Mesogeiakon Meleton, 1990); Marina FrolovaWalker, Russian Music and Nationalism from Glinka to Stalin (New Haven, CT: Yale University Press, 2007); Glenda Dawn Goss, Sibelius: A Composer's Life and the Awakening of Finland (Chicago: Chicago University Press, 2009); Martina Grempler, Rossini e la Patria. Studien zu Leben und Werk Gioacchino Rossinis vor dem Hintergrund des Risorgimento (Kassel: Bosse, 1996); Rutger Helmers, 'Not Russian enough: The Negotiation of Nationalism in Nineteenth-Century Russian Opera', doctoral thesis (Utrecht: Utrecht University, 2012); Václav Holzknecht, Bedřich Smetana: Život a Dilo (Praha: Panton, 1979); Krisztina Lajosi, 'National Opera and Nineteenth-Century NationBuilding in East-Central Europe', Neohelicon: Acta Comparationis Litterarum Universarum 32, no. 1 (2005): 51-70; Joseph J. Ryan, 'Nationalism and Music in Ireland', doctoral thesis (Maynooth: National University of Ireland, 1991); Jim Samson, 'Nations and Nationalism', in The Cambridge History of Nineteenth-Century Music (Cambridge: Cambridge University Press, 2002), 568-600; Michael C. Tusa, 'Cosmopolitanism and National Opera: Weber's Der Freischütz', Journal of 
Interdisciplinary History 36, no. 3 (2006): 483-506; Harry White and Michael Murphy, eds., Musical Constructions of Nationalism. Essays on the History and Ideology of European Musical Culture, 1800-1945 (Cork: Cork University Press, 2001).

25 Quoted in Jeffrey Richards, Imperialism and Music: Britain, 1876-1953 (Manchester: Manchester University Press, 2001), 12. Cf. generally Christoph Mährlein, Volksgeist und Recht: Hegels Philosophie der Einheit und ibre Bedeutung in der Rchtswissenschaft (Würzburg: Königshausen \& Neumann, 2000). How the semantics of the neologism Volksgeist relates to the slightly older Nationalcharakter is an intriguing challenge to conceptual historians; in the usage of these decades, the two are by no means interchangeable. It should also be noted that as the term Volksgeist emerges, so does the notion of Volkstum (coined by Friedrich Ludwig Jahn in his book of that title, 1810), while Arndt in his Geist der Zeit pamphlets prepared the coinage of the parallel term Zeitgeist.

27 Edmund Burke, Reflections on the Revolution in France, ed. L. G. Mitchell (Oxford: Oxford University Press, 1993), 96-7.

28 For what follows, generally my 'Ossian and the Rise of Literary Historicism', in The Reception of Ossian in Europe, ed. H. Gaskill (London: Continuum, 2004), 109-25 and 'Literary Historicism: Romanticism, Philologists, and the Presence of the Past', Modern Language Quarterly 65, no. 2 (2004): 221-43.

29 The best recent introduction is the biography by Steffen Martus, Die Brüder Grimm: Eine Biographie (Berlin: Rowohlt, 2010).

30 Wilhelm Schoof, ed., Briefe der Brüder Grimm an Savigny (Berlin: Erich Schmidt, 1953); for the continuing indebtedness, see Ruth Schmidt-Wiegand, 'Das Sinnliche Element des Rechts. Jacob Grimms Sammlung und Beschreibung Deutscher Rechtsaltertümer', in Kasseler Vorträge in Erinnerung an den 200. Geburtstag der Brüder Jacob und Wilhelm Grimm, ed. L. Denecke (Marburg: Elwert, 1987), 1-24. Also, my 'From Bökendorf to Berlin: Private Careers, Public Sphere, and how the Past Changed in Jacob Grimm's lifetime', in L. Jensen et al., eds., Free Access to the Past: Romanticism, Cultural Heritage and the Nation, 55-70.

31 Heinz Rölleke, 'Die Beiträge der Brüder Grimm zu “Des Knaben Wunderhorn” ', Brüder Grimm Gedenken 2 (1975), 28-42.

32 Maria Herrlich, Organismuskonzept und Sprachgeschichtsschreibung. Die 'Geschichte der deutschen Sprache' von Jacob Grimm (Hildesheim: Olms-Weidmann, 1998).

33 The idea that the language is not a general-human capacity but the cultural and intellectual DNA of each separate nation was formulated most forcefully by Wilhelm von Humboldt. Cf. Pierre Caussat, Dariusz Adamski, and Marc Crépon, eds., La Langue Source de la Nation: Messianismes Séculiers en Europe Centrale et Orientale (du XVIIIe au XXe siècle) (Sprimont: Mardaga, 1996).

34 From the huge body of literature on the topic I mention only Max Behland, 'Nationale und nationalistische Tendenzen in Vorreden zu wissenschaftlichen Werken', in Nationalismus in Germanistik und Dichtung, ed. B. von Wiese and R. Henß (Berlin: Schmidt, 1967), 334-46; Johannes Janota, Eine Wissenschaft Etabliert sich, 1810-1870 (Tübingen: Niemeyer, 1980); Katinka Netzer, Wissenschaft aus Nationaler Sehnsucht: Verhandlungen der Germanisten 1846 und 1847 (Heidelberg: Winter, 2006).

35 'Piety towards one's ancestors is the strongest bonding agent of a nation; of those who are mindful of the intellectual and scholarly standing of our country amidst other peoples, of all 
those who, across the centuries of its history, cherish that 'sweet France' for which one was already prepared at Roncesvalles to die a good death.'

The original also contained the following passage: 'Nous faisons appel ... à tous ceux qui aiment la France de tous les temps, à tous ceux qui croient qu'un peuple qui répudie son passé prépare mal son avenir, et à tous ceux qui savent que la conscience nationale n'est pleine et vivante que si elle relie dans un sentiment profond de solidarité les générations présentes à celles qui se sont éteintes.' Quoted in Charles Ridoux, Évolution des Études médiévales en France de 1860 à 1914 (Paris: Champion, 2001), 410 and 425. Building in 19th-Century Europe (Amsterdam: Rodopi, 2008). 'Of the three poetic genres, none is more difficult to judge than the epic. For lyrical poetry, arising as it does out of the human heart itself, turns directly to our feelings and is understood from all periods in all periods, and dramatic poetry attempts to translate the past into the frame of reference-the language, as it were-of the present, and cannot fail to impress us when it succeeds. But the case is far different with epic poetry. Born in the past, it reaches over to us from this past, without abandoning its proper nature, and if we want to savor it, we must project ourselves into wholly vanished conditions.' Jacob Grimm, 'Über das finnische Epos', in Kleinere Schriften, vol. 2 (Berlin: Dümmler, 1865), 75.

38 Generally on this topic, see my 'Oral epic: The Nation Finds a Voice', in Folklore and Nationalism during the Long Nineteenth Century, ed. T. Baycroft \& D. Hopkin (Leiden: Brill, 2012), 11-26.

39 Jean-Yves Guiomar, 'Le Barzaz-Breiz de Théodore Hersart de la Villemarqué”, in Les Lieux de Mémoire, ed. Pierre Nora, vol. 3 (Paris: Gallimard, 1997), 3479-514. Gaela Keryell, "The "Kalevala" and the "Barzaz-Breiz": The Relativity of the Concept of "Forgery" ', in A. Ahlquist et al., eds., Celtica Helsingiensia: Proceedings from a Symposium on Celtic Studies (Helsinki: Societas Scientiarium Fennica, 1996), 57-104. Edward L. Keenan, Josef Dobrovsky and the Origins of the Igor Tale (Cambridge, MA: Harvard University Press, 2001). Also: Mary-Ann Constantine, The Truth against the World: Iolo Morganwg and Romantic Forgery (Cardiff: University of Wales Press, 2007).

40 Ann Rigney, Imperfect Histories: The Elusive Past and the Legacy of Romantic Historicism (Ithaca, NY: Cornell University Press, 2001). Id., The Afterlives of Walter Scott: Memory on the Move (Oxford University Press, 2012).

41 Monika Baár, Historians and the Nation in the Nineteenth Century: The Case of East-Central Europe (Oxford: Oxford University Press, 2010); Stefan Berger, M. Donovan and K. Passmore, eds., Writing National Histories. Western Europe since 1800 (London: Routledge, 1999). Stefan Berger and Chris Lorenz, eds., Nationalizing the Past: Historians as Nation Builders in Modern Europe (Basingstoke: Palgrave Macmillan, 2008). Dennis Deletant and Harry Hanak, eds., Historians as NationBuilders. Central and South-East Europe (London: Macmillan / School of Slavonic and East European Studies, 1988).

42 Ann Rigney, The Rhetoric of Historical Representation: Three Narrative Histories of the French Revolution (Cambridge, MA: Cambridge University Press, 1990). Boris Réizov, L’historiographie Romantique Française, 1815-1830 (Moscou: Editions en Langues Étrangères, 1962).

43 Françoise Baudson, Le Style Troubadour (Bourg-en-Bresse: Brou, 1971). Sam Smiles, The Image of Antiquity: Ancient Britain and the Romantic Imagination (New Haven, CT: Yale University Press, 1994). 
A similar trajectory from classicist to nationalist we can notice in the literary genre that precedes the historical novels and runs alongside that of the history painting: the historical drama. While Home's Douglas is an early example of a national-historical tragedy, the non-classical tragic heroes that Goethe and Schiller choose for their Weimar period, while they may be nationally German (Götz von Berlichingen and, at a pinch, Wallenstein and Wilhelm Tell), can as easily be from other parts of Europe: Jeanne d'Arc, Egmont. However, post-Schiller playwrights like Adam Oehlenschläger and even the early Ibsen use the theatre to bring, specifically, the nation's own past 'back to life'.

45 The case of Belgium has been covered by Judith Ogonovsky: 'La Peinture Monumentale, "Manière Parlante d'Enseigner l'Historie Nationale" ', in Les Grands Mythes de l'Histoire de Belgique, de Flandre et de Wallonie, ed. A. Morelli (Bruxelles: Vie ouvrière, 1995), 163-74. Id., La Peinture Monumentale d'Histoire dans les Édifices Civils de Belgique (1830-1914) (Brussel: Académie royale de Belgique, 1999). The case of Germany emerges from the in-depth study of the Goslar murals by Monika Arndt, Die Goslarer Kaiserpfalz als Nationaldenkmal: Eine ikonographische Untersuchung (Hildesheim: Lax, 1976). Further: Alice Laura Arnold, 'Poetische Momente der Weltgeschichte: Die Wandbilder im Schloss Hohenschwangau', doctoral thesis (München: Ludwig-MaximiliansUniversität, 2006); Reinhold Baumstark and Frank Büttner, eds., Großer Auftritt: Piloty und die Historienmalerei (München: Pinakothek-Dumont, n.d.). Julius Fekete, Carl von Häberlin (1832-1911) und die Stuttgarter Historienmaler seiner Zeit (Sigmaringen: Thorbecke, 1986). Gabriella Szvoboda Dománszky Régi Dicsóségünk: Magyar Históriai Képek a XIX. Században (Budapest: Corvina, 2001). Michael Huig, 'Tot eer van Bohemen: De verbeelding van nationale geschiedenis, circa 17891848', doctoral thesis, 2 vols. (Amsterdam: Universiteit van Amsterdam, 2005). David Jackson and Patty Wageman, eds., Akseli Gallen-Kallela: The Spirit of Finland (Rotterdam: NAi Publishers, 2006). Karl Koetschau, Alfred Rethels Kunst vor dem Hintergrund der Historienmalerei seiner Zeit (Düsseldorf: Kunstverein für die Rheinlande und Westfalen, 1927). Doris Lehmann, Historienmalerei in Wien: Anselm Feuerbach und Hans Makart im Spiegel Zeitgenössischer Kritik (Köln: Böhlau, 2011). Peter Murray, ed., Daniel Maclise (1806-1870): Romancing the Past (Cork: Crawford Art Gallery and Gandon Editions, 2008). Barbara Rommé, Moritz von Schwind - Fresken und Wandbilder (OstfildernRuit: Hatje, 1996). Marie Schäfer, 'Historienmalerei und Nationalbewusstsein in Russland 1860189o', doctoral thesis (Köln: U zu Köln, 1985). Franz Zelger, Heldenstreit und Heldentot: Schweizerische Historienmalerei im 19. Jabrbundert (Zürich: Atlantis, 1973). Ursula Ziem, 'Die Spanische Historienmalerei des 19. Jahrhunderts', doctoral thesis (Stuttgart: Stuttgart University, 2007).

46 I mention in passing the vogue of engravings and book illustrations as intermedial visualizations of the past; cf. Adolf Bär and Paul Quensel's 189o Bildersaal Deutscher Geschichte: Zwei Jahrtausende Deutschen Lebens in Wort und Bild, mit 483 Abbildungen und 48 Kunstbeilagen nach Originalen Hervorragender Künstler (reprint Wiesbaden: Marix, 2004), and Tom Verschaffel, Beeld en Geschiedenis: Het Belgische en Vlaamse Verleden in de Romantische Boekillustraties (Turnhout: Brepols, 1987).

47 On the national function of public monuments in these decades, most analyses follow Thomas Nipperdey's path-breaking article 'Nationalidee und Nationaldenkmal in Deutschland im 19. Jahrhundert', Historische Zeitschrift 206 (1968): 529-85. Also, Maurice Agulhon, 'La "Statuomanie" et l'Histoire', in Id., Histoire Vagabonde I: Ethnologie et Politique dans la France Contemporaine (Paris: Gallimard, 1988), 137-85. 
48 Also - and this is a point hitherto perhaps insufficiently noted in Scott studies - Scott, a lawyer himself, is continually at pains to stress the fact that Scotland maintained, even after the Unions of the Crowns and of the Parliaments, its own legal system. The constant undercurrent of legal references in the Waverley Novels, when read in the light of Savigny-style legalistic organicism and historicism, show (I submit) that Scott firmly claimed an autonomous, subsidiary but never subaltern, status for Scotland within the British context.

49 John Prebble, The King's Jaunt: George IV in Scotland, August 1822. 'One and twenty daft days' (Edinburgh: Birlinn, 1996).

50 Murray Pittock, ed., The Reception of Sir Walter Scott in Europe (London: Continuum, 2007).

51 Walter Gobbers, 'Consciences Leeuw van Vlaenderen als Historische Roman en Nationaal Epos: Een Genrestudie in Europees Perspectief', in A. Deprez and W. Gobbers, eds., Vlaamse Literatuur van de Negentiende Eeuw. Dertien Verkenningen (Utrecht: HES, 1990), 45-69. 